\title{
The Relationship between $H$. pylori Virulence Genotypes and Gastric Diseases
}

\author{
YUN EN LIU, YUE HUA GONG, LI PING SUN, QIAN XU and YUAN YUAN* \\ Tumor Etiology and Screening Department of Cancer Institute and General Surgery, \\ the First Affiliated Hospital of China Medical University \\ and Key Laboratory of Cancer Control in Liaoning Province, Shenyang, China
}

Received 22 September 2011, revised 7 February 2012, accepted 7 May 2012

\begin{abstract}
There have been no reports on the relationship between virulence genes and gastric diseases based on the same bacterial colonization density. Our results indicated that Helicobacter pylori virulence genes were more relevant than colonization density as a pathogenic mechanism of gastric diseases, which helps elucidate the pathogenic mechanisms of bacteria and aids in the development of improved strategies for the treatment of gastric disease.
\end{abstract}

Ke y words: H. pylori, colonization density, cagA, vacA, iceA

Approximately half of the world's population is infected with Helicobacter pylori and it has been associated with chronic gastritis, peptic ulcer and gastric carcinoma (Momtaz et al., 2010). Most infected people remain asymptomatic, and only $15-20 \%$ of $H$.pylori positive individuals develop the associated diseases (Franco et al., 2008). Why some infected people develop these sequelae and others do not is unknown, but one possible explanation is that some H. pylori strains are more pathogenic than others. Over the last few years, increased attention has been given to the significance of $H$. pylori virulence genes, such as the vacuolating cytotoxin $(\operatorname{vac} A)$, the cytotoxin associated gene $\mathrm{A}(\operatorname{cag} A)$ and a gene induced by contact with the gastric epithelium (iceA)(Boyanova et al., 2009). Nevertheless, the clinical relevance of the virulence associated genes of $H$. pylori is still a matter of controversy. Several studies have reported an influence of virulence genes on the clinical outcomes of $H$. pylori infections in different geographical regions. One hypothesis for why these strains are associated with different clinical outcomes is that there is a marked discrepancy between the number of individuals colonized and those with clinical symptoms. Low bacterial colonization density was correlated significantly with mild degrees of gastric neutrophil infiltration (Kaklikkaya et al., 2006) and macroscopic erosions (Molnar et al., 2008), and high bacterial den- sity was more significantly associated with peptic ulcers than chronic gastritis (Boyanova, 2007). Therefore, quantified bacterial density is optimal for helping elucidate the pathogenic mechanisms of $H$. pylori and aiding in the development of improved strategies for the treatment of gastric disease.

The aim of our study was to explore the relationship between virulence-associated genes and gastric diseases based on the same bacterial colonization density.

This study was approved by the Ethics Committee of the China Medical University and all subjects signed an informed consent form before inclusion. A total of 174 patients (99 males and 75 females, 30-82 y, mean age $53 \mathrm{y}$ ) were involved in the study. Three biopsy specimens from each patient were placed in $10 \%$ formalin and processed in paraffin blocks. All sections were stained with hematoxylin and eosin and a single experienced pathologist reviewed all the slides according to the criteria proposed in the updated Sydney system. The distribution of clinical disease was as follows: 67 patients had superficial gastritis (SG); 20 patients had gastric ulcer (GU); 63 patients) had atrophic gastritis (AG) and 24 patients had gastric cancer (GC).

Detection of $H$. pylori was carried out by immunohistochemical staining using polyclonal anti-H. $p y$ lori antibody and peroxidase-conjungated streptavidin (DAKO A/S, Denmark). We graded the density of

* Corresponding author: Y. Yuan, The First Affiliated Hospital of China Medical University, 155 Northern Nanjing Street, Heping District, Shenyang 110001, Liaoning Province, China; phone: 024-83282292, e-mail: yyuan3@hotmail.com 

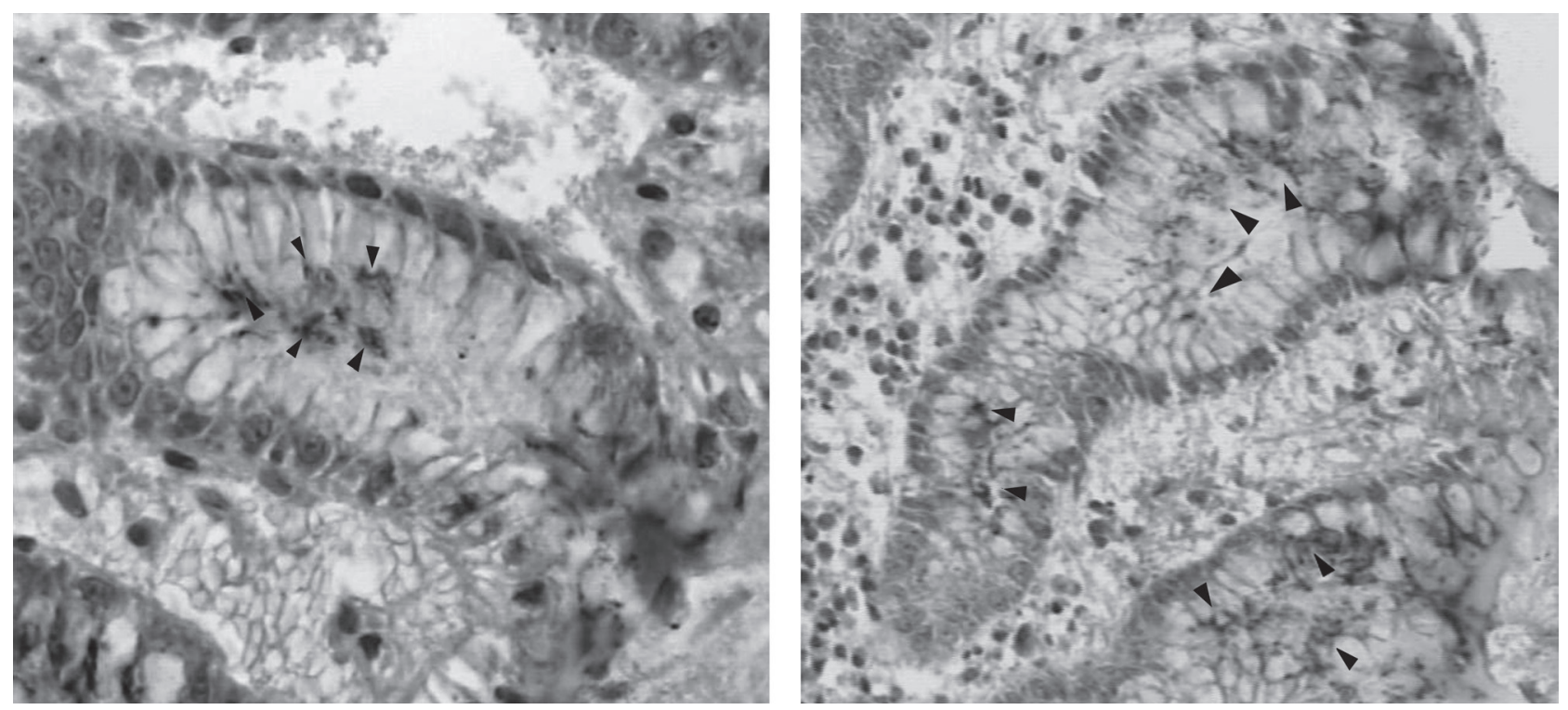

Fig. 1. Representative gastric sections stained immunohistochemically for anti-H.pylori-IgG. H pylori(arrow) were stained brown and were demonstrated on the apical and/or lateral surface of the surface mucous cells on which $H$. pylori were seen as small aggregates with detached epithelial cells.

A: low bacterial density (original magnification $\times 200$ ); B: moderate to severe bacterial density (original magnification $\times 100$ )

H. pylori infection according to the number of individual bacteria that were counted in a highly magnified visual field ( $\times 1000$ light-microscopy) (Fig. 1). The density of $H$. pylori infection was defined as follows: $0=0 ; 1+=1-9 ; 2+=10-29$; and $3+=30-99$. Details of the method have been published elsewhere (Tokunaga et al., 2000).

In this study, we extracted H.pylori-DNA directly from gastric tissues infected by $H$. pylori. PCR amplifications (Table I) were performed in an automated thermal cycler. PCR products were analyzed by $1 \%$ agarose gel electrophoresis with ethidium bromide staining and were visualized under a short wavelength ultraviolet light source. The results were analyzed using the $\mathrm{x} 2$ test and with Yates continuity correction and the Fisher exact test. Results were considered statistically significant when the $p$-values were less than 0.05 .

The results showed that patients suffering from SG, GU, AG and GC were predominantly affected by moderate to severe bacterial infection. Bacterial colonization density was moderate to severe (grades 2-3) in 53/67 of SG strains and 47/63 of AG strains, showing there was no significant correlation between the density of the bacterial colonization and the presence

Table I

Polymerase chain reaction for amplification of $\operatorname{cag} A, v a c A$ and ice $A$ genes

\begin{tabular}{|c|c|c|c|}
\hline Region & Prime & Nucleotide sequence (5'-3') & Size of product (bp) \\
\hline \multirow[t]{2}{*}{$\operatorname{cag} \mathrm{A}$} & CAGAF & GGCAATGGTGGTCCTGAGGCTAGGC & \multirow[t]{2}{*}{324} \\
\hline & CAGAR & GAGAATCTTTAATCTCAGTTCGG & \\
\hline \multirow[t]{2}{*}{$\operatorname{vacAs} 1 / \mathrm{s} 2$} & VA1-F & ATGAGAATACAACAAACACAC & \multirow[t]{2}{*}{$259 / 286$} \\
\hline & VA1-R & CTGCTTAGATGCGCCAAAC & \\
\hline \multirow[t]{2}{*}{ vacA mla } & VA3-F & GGTCAAAATGCGGTCATGG & \multirow[t]{2}{*}{290} \\
\hline & VA3-R & CCATTGGTACCTGTAAGAAC & \\
\hline \multirow[t]{2}{*}{ vacAm1b } & VAM-F3 & GGCCCCAATGCAGTCATGAGT & \multirow[t]{2}{*}{291} \\
\hline & VAM-R3 & GCTGTTAGTGCCTAAAAGAGCAT & \\
\hline \multirow[t]{2}{*}{ vacAm2 } & VA4-F & GAGGCCCCAGAGAACATTG & \multirow[t]{2}{*}{352} \\
\hline & VA4-R & CATAACTAGCGCCTTGCAC & \\
\hline \multirow[t]{2}{*}{ iceA1 } & ICEA1F & GTGTTTTTAACCAAAGTATC & \multirow[t]{2}{*}{247} \\
\hline & IVEA1R & CTATAGCCASTYTCTTTGCA & \\
\hline \multirow[t]{2}{*}{ iceA2 } & ICEA2F & GTTGGGTATATCACAATTTAT & \multirow[t]{2}{*}{334} \\
\hline & ICEA2R & TTRCCCTATTTTCTAGTAGGT & \\
\hline
\end{tabular}


Table II

Distribution of bacterial colonization density in patients

\begin{tabular}{|l|c|c|c|}
\hline \multirow{2}{*}{$\begin{array}{c}\text { Gastric } \\
\text { diseases }\end{array}$} & \multicolumn{2}{|c|}{ Bacterial colonization density } & \multirow{2}{*}{ Total } \\
\cline { 2 - 3 } & $0-1$ & $2-3$ & \\
\hline SG & $14(20.90)$ & $53(79.10)$ & 67 \\
\hline GU & $3(15.00)$ & $17^{\text {a }}(85.00)$ & 20 \\
\hline AG & $16(25.40)$ & $47^{\text {b }}(74.60)$ & 63 \\
\hline GC & $9(37.50)$ & $15^{\text {c }}(62.50)$ & 24 \\
\hline Total & 34 & 66 & 174 \\
\hline
\end{tabular}

0-1,low bacterial density; $2-3$, moderate to severe bacterial density; ${ }^{\mathrm{a}} \mathrm{p}=0.7931 \mathrm{vs} \mathrm{SG} ;{ }^{\mathrm{b}} \mathrm{p}=0.689 \mathrm{vs} \mathrm{SG} ;{ }^{\mathrm{c}} \mathrm{p}=0.183 \mathrm{vs} \mathrm{SG}$ gastric diseases compared to the density of bacterial colonization, it should be recognized that most patients suffering from SG, AG and GC that were infected by bacteria were from areas with a higher prevalence of gastric cancer and where moderate to severe density of $H$. pylori was prevalent, which suggests that the high bacterial colonization density, to a lesser degree, may be a factor in the development of $H$. pylori induced gastric diseases. Many more cases need to be further evaluated to provide more reliable results about the relationship between specific genotypes and gastric diseases based on the same density of bacteria.

Table III

Distribution of bacterial genotypes in patients based on the same bacterial density (grade 2-3)

\begin{tabular}{|c|c|c|c|c|c|c|c|}
\hline \multirow{2}{*}{ Diseases } & \multicolumn{6}{|c|}{ H. pylori genotypes (\%) } & \multirow{2}{*}{ Total } \\
\hline & cagA & vacAs1 & vacAm1 & vacAm2 & iceA1 & iceA2 & \\
\hline SG & $30(56.60)$ & $48(90.57)$ & $36(67.92)$ & $17(32.08)$ & $35(66.04)$ & $30(56.60)$ & 53 \\
\hline GU & $10(58.82)$ & $17(100.00)$ & $10(58.82)$ & $12^{\mathrm{d}}(70.59)$ & $10(58.82)$ & $11(64.71)$ & 17 \\
\hline $\mathrm{AG}$ & $21(44.68)$ & $30(63.83)$ & $15^{\mathrm{a}}(31.91)$ & $40^{c}(85.11)$ & $22(46.81)$ & $20(42.55)$ & 47 \\
\hline GC & $7(46.67)$ & $11(73.33)$ & $3^{\mathrm{b}}(20.00)$ & $7(46.67)$ & $4^{\mathrm{e}}(26.67)$ & $7(46.67)$ & 15 \\
\hline Total & $68(51.52)$ & $106(80.30)$ & $64(48.48)$ & $76(57.58)$ & $71(53.79)$ & $68(51.52)$ & 132 \\
\hline
\end{tabular}

${ }^{a} \mathrm{P}=0.000$ vs SG; ${ }^{b} \mathrm{P}=0.001$ vs $\mathrm{SG}$; ${ }^{\mathrm{c}} \mathrm{P}=0.000$ vs SG; ${ }^{\mathrm{d}} \mathrm{P}=0.002$ vs SG; ${ }^{\mathrm{e}} \mathrm{P}=0.015 \mathrm{vs} \mathrm{SG}$

of atrophic gastritis $(p=0.689)$. In addition, bacterial density was moderate to severe (grades $2-3$ ) in 53/67 of SG strains and 15/24 of GC strains, showing there was no significant correlation between the density of the bacterial colonization and GC $(p=0.183)$ (Table II). SG patients more often harbored strains with the $v a c A m 1$ genotype $(67.92 \%, 36$ of 53 cases) than the AG or GC patients $(31.91 \%, 15$ of 47 cases, $p=0.000$ and $20.00 \%, 3$ of 15 cases, $p=0.001$, respectively). In addition, AG patients more often harbored strains with the vacAm2 genotype $(85.11 \%, 40$ of 47 cases) than the SG patients $(32.08 \%, 17$ of 53 cases, $p=0.000)$ (Table III).

In order to exclude interference from the density of bacteria, we explored the relationship between H. pylori virulence genes and gastric diseases based on the same colonization density. We first found the vacAm2 strain was significantly associated with AG. Few have reported an association between $v a c A m 2$ and gastric diseases except vacAm 2 strains were associated with gastritis in Iranian patients (Dabiri et al., 2010). The reason why $v a c A m$ alleles induce different types of gastritis might be that the $m 1$ and $m 2$ forms of the VacA cytotoxin may recognize different receptors on human gastric epithelial cells (Nogueira et al., 2001), and there is a higher level of cytotoxin production by vacA $s 1 / \mathrm{m} 1$ strains as compared to $v a c A s 1 / m 2$ strains. Although the results suggested virulence genes might play a critical role in
In conclusion, our results indicated that $H$.pylori virulence genes were more relevant than colonization density as a pathogenic mechanism of gastric diseases, which helps elucidate the pathogenic mechanisms of bacteria and aids in the development of improved strategies for the treatment of gastric disease.

\section{Acknowledgments}

This study was funded partly by the National Key Basic Research Program of China, (973 Program No.2010CB529304) and the Foundation of the Key Laboratory in Liaoning Province (No.LS2010167) and the Foundation of the Technology Project of Liaoning Province (2008-621).

\section{Literature}

Franco A.T., E. Johnston and U. Krishna. 2008. Regulation of gastric carcinogenesis by Helicobacter pylori virulence factors. Cancer Res. 68: 379-87.

Boyanova L. 2007. Detection of Helicobacter pylori infection in symptomatic Bulgarian adults. Clin. Microbiol. Infect. 13: 908-914. Nogueira C., C. Figuiredo and F. Carneiro. 2001. Helicobacter pylori genotypes may determine gastric histopathology. Am. J. Pathol. 158: 647-654.

Dabiri H., M. Bolfion and A. Mirsalehian. 2010. Analysis of Helicobacter pylori genotypes in afghani and Iranian isolates. Pol. J. Microbiol. 59: 61-66.

Momtaz H., N. Souod and H. Dabiri. 2010. Comparison of the virulence factors of Helicobacter pylori isolated in Stomach and Saliva in Iran. Am. J. Med. Sci. 340: 345-349. 
Boyanova L., R. Markovska and D. Yordanov. 2009. High prevalence of virulent Helicobacter pylori strains in symptomatic Bulgarian patients. Diagn. Micr. Infec. Dis. 64: 374-380.

Molnar B., D. Szoke and A. Ruzsovics. 2008. Significantly elevated Helicobacter pylori density and different genotype distribution in erosions as compared with normal gastric biopsy specimen detected by quantitative real-time PCR. Eur. J. Gastroenterol. Hepatol. 20: 305-313.
Kaklikkaya N., K. Cubukcu and F. Aydin. 2006. Significance of cagA status and vacA subtypes of Helicobacter pylori in determining gastric histopathology: Virulence markers of $H$. pylori and histopathology. J. Gastroen. Hepatol. 21: 1042-1047.

Tokunaga Y., H. Shirahase and E. Yamamoto. 2000. Modified rapid urease test for Helicobacter pylori detection in relation to an immunohistochemical stain. J. Gastroen. Hepatol. 15: 617-621. 